\title{
ARTICLES
}

\section{Communis Opinio and Jus Cogens: A Critical Review on Pro-Torture Law and Policy Argument}

\author{
Gary Lilienthal ${ }^{*} \&$ Nehaluddin Ahmad ${ }^{* *}$
}

The prohibition on torture has attained status as a peremptory norm of general international law. This gives rise to the obligation erga omnes to take action against those who torture. Despite this, most world states routinely conduct torture. Is there really a worldwide prohibition of torture? Argument is framed to demonstrate that the concept of a jus cogens peremptory norm, flowing erga omnes to all nations, is in practice unattainable, preventing any absolute and universal international law prohibition against torture. States cannot declare someone an enemy of all mankind, or bind all other states to that view. Jus cogens is a text writers' municipal communis opinio, but held administratively to be based in customary international law. Any prohibition against torture appears to remain in municipal customary law form, breaches of which are proved as arguments based on fact, eliminating operation of any absolute peremptory governing norm.

\section{Keywords}

Torture, Jus Cogens, Erga Omnes, Enemy of All Mankind, Communis Opinio, Customary International Law

* Professor of Law at School of Law of the University of Gondar, Ethiopia. Dip. Counselling (A.I.P.C.), LL.B./Grad. Dip. Legal Practice (Sydney), M. Psychoanalytic Studs. (Deakin Univ., Australia), Ph.D. (Curtin Univ., Australia). ORCID: http://orcid.org/0000-0002-1875-0294. The author may be contacted at: carringtonrand@icloud.com/Address: School of Law, University of Gondar, P.O. Box 196, Gondar, Ethiopia.

** Professor, Department of Law, Sultan Sharif Ali Islamic University (UNISSA), Brunei Darussalam. MA/LL.B./LL.M. (Lucknow Univ., India), LL.M. (Strathclyde Univ., UK), LL.D. (Meerut Univ., India). ORCID: http://orcid.org/00000003-1193-2092. The author may be contacted at: ahmadnehal@yahoo.com/Address: Sultan Sharif Ali Islamic University (UNISSA), Spg. 347 Jalan Pasar Baharu, Gadong, Brunei Darussalam, BE1310.

DOI: http://dx.doi.org/10.14330/jeail.2017.10.2.03 


\section{Introduction}

After publishing apparently accepted moral and legal arguments in support of a worldwide ban on torture in 2016, ${ }^{1}$ our colleagues asked us to argue the opposite case. Posner had already argued that states had no moral obligation to any compliance with international law. ${ }^{2}$ Further, Guzman argued it was unlikely that international law could influence any decisions of fundamental state importance, with any repeatable regularity. ${ }^{3}$ In respect of international law touching the field of torture, Amnesty International made the following observation:

Between January 2009 and May 2013, Amnesty International received reports of torture and other ill-treatment committed by state officials in 141 countries, and from every world region. This only indicates cases reported to or known by the organization and does not necessarily reflect the full extent of torture worldwide. As these statistics err firmly on the side of caution, the actual prevalence of torture and other ill-treatment is probably even worse. ${ }^{4}$

Having already published controversial arguments against a "rules-based order of international law," worldwide prohibition of torture.

The right to freedom from torture is written in many human rights instruments. These instruments are said to protect all individuals from being intentionally subjected to severe physical or psychological distress by, or with the approval or acquiescence of, government agents acting for a specific purpose, including to inflict punishment or to obtain information. ${ }^{6}$ The United Nations Convention against Torture and Other Cruel, Inhuman or Degrading Treatment or Punishment ("UNCAT") ${ }^{7}$ provides the most precise and widely-cited definition of torture under international law. It defines 'torture' as:

1 G. Lilienthal \& N. Ahmad, Proscribing Torture: an Analysis in Indian and Ethical Contexts: (The 2010 Indian Prevention of Torture Bill), 42 Commonwealth L. Bull. 38 (2016).

2 E. Posner, Do States Have a Moral Obligation to Obey International Law?, 55 STAN. L. Rev. 1901 (2003).

A. Guzman, A Compliance-Based Theory of International Law, 90 CALIF. L. Rev. 1886 (2002).

4 Amnesty International, Torture in 2014: 30 Years of Broken Promises 10 (2014).

5 G. Lilienthal \& N. Ahmad, The South China Sea Islands Arbitration: Making China's Position Visible in Hostile Waters, 18 Asian-PACIFIC L. \& PoL'y J. 83 (2017). The authors argue against a rules based order of international law.

UNCAT art. 1, 1465 U.N.T.S. 85.

7 Id. 
any act by which severe pain or suffering, whether physical or mental, is intentionally inflicted on a person for such purposes as obtaining from him or a third person information or a confession, punishing him for an act he or a third person has committed or is suspected of having committed, or intimidating or coercing him or a third person, or for any reason based on discrimination of any kind, when such pain or suffering is inflicted by or at the instigation of or with the consent or acquiescence of a public official or other person acting in an official capacity. It does not include pain or suffering arising only from, inherent in or incidental to lawful sanctions. ${ }^{8}$

One of the most universally recognized human rights, the prohibition on torture, according to de Wet, has attained status as a jus cogens or peremptory norm of general international law. This is said to give rise to the obligation erga omnes to take action against those who torture. 'Erga omnes means 'towards all' or 'towards everyone,' where rights and their correlated obligations are owed to all. A property right is an erga omnes entitlement, so that it is enforceable against any infringement of that right. An erga omnes right is thus cognate to a statutory right, and distinguished from a contractual right, which is enforceable only against the contracting party.

In international law, the term erga omnes suggests obligations states owe to the entire global community. An erga omnes obligation exists because of an identifiable universal and undeniable interest in perpetuating critical rights and preventing their breach, with any state having the right to complain of the breach. Erga omnes norms include genocide and piracy. ${ }^{10}$ However, despite the prohibition of torture, apparently as a jus cogens peremptory norm, flowing erga omnes to all nations, it appears as paradoxical that a good proportion of the world's states, and probably many private organizations operating with either state control or acquiescence, are routinely conducting torture. Thus, the question arises as to whether or not there really is a worldwide prohibition of torture. In this article, the argument is framed to demonstrate that the very concept of a jus cogens peremptory norm, flowing erga omnes to all nations, is in practice unattainable. Synthesizing the facts and evidence with this thesis statement, there cannot be any such absolute and universal international law prohibition against torture.

We have strongly argued against the use of torture based on both normative

Id.

Vienna Convention on the Law of Treaties of 1969 ("VCLT"), art. 53, 1155 U.N.T.S. 331. See E. de Wet, The Prohibition of Torture as an International Norm of Jus Cogens and its Implications for National and Customary Law, 15 Eur. J. InT'L L. 97 (2004).

10 VCLT art. 53. 
ethics, law and parliamentary administration. ${ }^{11}$ Now, we propose to argue the opposite view, vigorously, so that those faced with the terrible decision of whether or not to use torture can be better informed. Allhoff deployed a philosophical methodology to argue in favour of torture. However, he used a completely different methodology to what we will use in this argument. His philosophical view was that "if torture is permissible given any of the dominant moral theories (and if one of those is correct), then torture is permissible simpliciter."12 Other arguments, especially legal arguments, have tended to be based on statutory interpretation, ${ }^{13}$ or on the famous ticking time-bomb case. ${ }^{14}$ Therefore, the authors seek to remove the artefacts of research into positive law, and its justifications. Since any legal proscription of torture is argued through a jus cogens, as the threshold issue, we will conduct a legally synchronic ${ }^{15}$ synthesis of the meaning of jus cogens, through critical analysis of the term's meanings at various times, as independent of any prior judicial decisions. This kind of methodology would jettison solely positive law, but proceed with its synchronic legal analysis, so as not to exclude relevant ideas merely for reasons of historicity. It would then try to re-frame the facts into a new explanation of jus cogens. This can be applied practically to the popular view that torture is subject to a jus cogens ban under international law.

This paper has five parts, including Introduction and Conclusion. Part two will briefly examine torture as jus cogens. Part three will analyze the details of general instances of jus cogens. Its objective is to synthesize a structural rule for the concept. Part four will critically review the case law, examining which cases could qualify as setting up bans on torture by jus cogens. This research will likely conclude that states can neither declare that someone is an enemy of all mankind, nor bind all other states to that view erga omnes. The fallacy of jus cogens is that it is a text writers' municipal communis opinio, but held administratively to be based in customary international law. Any prohibition against torture appears to remain in municipal customary law form, breaches of which are proved as arguments based on fact, eliminating operation of any absolute peremptory governing norm.

11 Lilienthal \& Ahmad, supra note 1, at 38.

12 F. Allhoff, A Defense of Torture: Separation of Cases, Ticking Time-bombs, and Moral Justification, 19 INT'L J. Applied Philosophy 243 (2005).

13 See, e.g., Memorandum from Jay S. Bybee, Assistant Attorney-General for the Office of Legal Counsel at the United States Department of Justice, to Alberto Gonzales, Counsel to the President (2002).

14 M. Strauss, Torture, 48 N.Y.L. School L. Rev. 227 (2004).

15 A. Giacalone Ramat et al., Synchrony and Diachrony: A Dynamic Interface 18 (2013). 


\section{Prohibition of Torture as Jus Cogens}

In Barcelona Traction, the International Court of Justice ("ICJ") recognized the erga omnes concept as follows: ${ }^{16}$

... an essential distinction should be drawn between the obligations of a State towards the international community as a whole, and those arising vis-à-vis another State in the field of diplomatic protection. By their very nature, the former are the concern of all States. In view of the importance of the rights involved, all States can be held to have a legal interest in their protection; they are obligations erga omnes. Such obligations derive, for example, in contemporary international law, from the outlawing of acts of aggression, and of genocide, as also from the principles and rules concerning the basic rights of the human person, including protection from slavery and racial discrimination. Some of the corresponding rights of protection have entered into the body of general international law ... others are conferred by international instruments of a universal or quasi-universal character. ${ }^{17}$

As such, this kind of prohibition may be enforced against a State, even if it has not ratified any of the relevant treaties. The prohibition is not subject to derogation, even in times of war or emergency. A jus cogens is a fundamental principle of international law. No state may derogate it under the contemporary international community.

Today, there is no express agreement as to which norms are jus cogens. Bassiouni views that the scope of jus cogens norms is genocide, maritime piracy, slavery, torture, refoulement and wars of aggression and territorial expansion. ${ }^{18}$ In Prosecutor v. Furundžija, ${ }^{19}$ the International Criminal Tribunal for the Former Yugoslavia ("ICTY") stated there was a jus cogens for the prohibition against torture. ${ }^{20}$ It also confirmed that every state was entitled "to investigate, prosecute and punish or extradite individuals accused of torture, who are present in a territory under its jurisdiction." ${ }^{21}$ This implied universal jurisdiction for cases of torture, because, as

16 Barcelona Traction case, (Belg.v. Spain), Judgment, 1970 I.C.J. Rep. 3 (Feb. 5).

17 Id. at 33-4.

18 M. Cherif Bassiouni, International Crimes: "Jus Cogens" and "Obligatio Erga Omnes," 59 L. \& Contemp. Probs. 68 (1996).

19 Prosecutor v. Furundžija, Case No. IT-95-17/1-T, Judgment (Int'l Crim. Trib. for the Former Yugoslavia Dec. 10, 1998), available at http:/www.icty.org/x/cases/furundzija/tjug/en/fur-tj981210e.pdf (last visited on Oct. 17, 2017).

20 Id. $\uparrow 114$ \& $153-156$.

21 Id. $\uparrow \uparrow 145 \& 156$. 
argued by the US in the 2002 Michael Domingues case, "22 "the torturer has become, like the pirate and the slave trader before him, hostis humani generis, an enemy of all mankind." ${ }^{23}$ In this regard, Jane Chong suggested an international form of outlawry. $^{24}$

Kissinger argued against universal jurisdiction by saying the concept was quite recent. ${ }^{25}$ The closest listing in Black's Law Dictionary was hostes humani generis, meaning enemies of the human race. ${ }^{26}$ Until recent times, this term referred only to hijackers, pirates, and similar, who committed their crimes outside any state. ${ }^{27}$ States are generally permitted universal jurisdiction over crimes as a matter of customary international law. Such crimes include genocide, crimes against humanity, war crimes, and torture. ${ }^{28}$

The concept of hostes humani generis converges on the principles of universal jurisdiction, jus cogens, and erga omnes. ${ }^{29}$ An offence might be subject to universal jurisdiction not because of its heinousness, or even because it might otherwise go unpunished. It is only because the committed offence violates a jus cogens, ${ }^{30}$ erga omnes, ${ }^{31}$ extending to the entire human race. Although the full version obligatio erga omnes appears to suggest that states are obliged rather than merely permitted to prosecute breaches of jus cogens norms, there is no consensus on any such duty or right. ${ }^{32}$ According to the German Civil Code, e.g., this obligation is sourced from the customary international law. ${ }^{33}$

States would find two legal sources for their universal jurisdiction over the international crimes. One is the treaties such as: the UNCAT of 1984; the Geneva Conventions of 1949 Additional Protocol I of 1977; the Genocide Convention; and

22 The Michael Domingues Case, Judgment, Inter-Am. Ct. H.R. (ser. C) No. 5 rev. 1913 (Oct. 22, 2002).

23 Id. (US argument).

24 J. Chong, Targeting the Twenty-First Century Outlaw, 122 YaLE L. J. 724 (2012).

25 H. Kissinger, The Pitfalls of Universal Jurisdiction, 80 Foreign Aff. 87 (2001).

26 See generally Black's Law Dictionary (6th ed. 1990).

27 Kissinger, supra note 25 , at 87.

28 A. Addis, Imagining the International Community: The Constitutive Dimension of Universal Jurisdiction, 31 Hum. RTs. Q. 136 (2009).

29 Bassiouni, supra note 18, at 65.

30 Jus cogens is defined by the Vienna Convention on the Law of Treaties as "a norm accepted and recognised by the international community of States as a whole as a norm from which no derogation is permitted and which can be modified only by a subsequent norm of general international law having the same character." See VCLT art. 53.

31 Barcelona Traction case (Belg. v. Spain), Judgment, 1970 I.C.J. Rep. 3, ๆ 33 (Feb. 5).

32 Bassiouni, supra note 18 , at 65.

33 Affirming the decision of the sentencing judge of the Düsseldorf Court of Appeals (Oberlandesgericht), it convicted a Bosnian Serb to life imprisonment for the crime of genocide under the universal jurisdiction of the German Criminal Code. See Decision of 12 December 2000, JuRISTEn-Zeitung 2001, at 975. < available only in German> 
the Statute of the International Criminal Court. ${ }^{34}$ These treaties do not expressly establish universal jurisdiction. ${ }^{35}$ However, the US, e.g., has interpreted them as authorizing and requiring their municipal courts to claim universal jurisdiction over core international crimes. ${ }^{36}$ The other is, as stated in the 2000 Case concerning the Arrest Warrant, ${ }^{37}$ customary international law. ${ }^{38}$

Cruel, inhuman or degrading treatment or punishment is usually prohibited in international instruments that forbid torture, as well. Cruel, inhuman or degrading ("CID") treatment, as compared to torture, involves a lower level of suffering and need not be inflicted for a specific purpose. ${ }^{39}$

\section{General Instances of Jus Cogens}

\section{A. Jus Cogens in Municipal Legal Systems}

Schwelb opined that the notion of an international jus cogens arose from municipal legal systems. ${ }^{40}$ He observed that the scholarship said the ancient Roman law knew of it. However, he could see no evidence of the term jus cogens in any of the Roman law sources. ${ }^{41}$

The concepts of 'ordre public,' or public policy, known to both the civil law and the common law systems are said to be cognate to, but really do not conform well to

34 UNCAT; Convention [No. 1] for the Amelioration of the Condition of the Wounded and Sick in Armed Forces in the Field, 12 August 1949, 75 U.N.T.S. 31; Convention [No. 2] for the Amelioration of the Condition of the Wounded, Sick, and Shipwrecked Members of Armed Forces at Sea, 12 August 1949, 75 U.N.T.S. 85; Convention [No. 3] Relative to the Treatment of Prisoners of War, 12 August 1949, 75 U.N.T.S. 135; Convention [No. 4] Relative to the Protection of Civilian Persons in Time of War, 12 August 1949, 75 U.N.T.S. 287; Protocol Additional to the Geneva Conventions of 12 August 1949, and Relating to the Protection of Victims of International Armed Conflicts, 8 June 1977, 1125 U.N.T.S. 3; Convention on the Prevention and Punishment of the Crime of Genocide, 9 December 1948, 78 U.N.T.S. 277; Rome Statute of the International Criminal Court, 17 July 1998, 2187 U.N.T.S. 3.

35 M. Cherif Bassiouni, The History of Universal Jurisdiction and Its Place in International Law, in UNIVERSAL Jurisdiction: National Courts and the Prosecution of Serious Crimes Under International Law 39, 50 \& 55-6 (S. Macedo ed., 2003).

3618 U.S.C. $\$ 1091$ (e) (2006) (genocide); 18 U.S.C. $\$ 2340$ A(b) (2006) (torture).

37 Case concerning the Arrest Warrant of 11 April 2000 (Congo v. Belg.), Judgment, 2002 I.C.J. Rep. 1 (Feb. 14).

38 Id. $ๆ 52$.

39 UNCAT, art. 1.

40 E. Schwelb, Some Aspects of International Jus Cogens as Formulated by the International Law Commission, 61 Ам. J. InT'L L. 948 (1967).

41 Id. 
that of jus cogens. ${ }^{42}$ The first European country to use the expression 'ordre public' was France, ${ }^{43}$ from which the term moved to other states of the Romanic group. Husserl stated that, by laws which affect the ordre public, it meant domestic rules with the character of jus cogens, meaning compulsory laws imposing a restriction upon the autonomy of individuals' will. Such laws could not be derogated from by private agreements. ${ }^{44}$ However, the notions of ordre public were not fully congruent, insofar as they have been used across Europe, England and America. Analyzing each concept to extract an exact definition in the comparison of ordre public is doomed to fail. ${ }^{45}$ The term 'public policy' is often used in an inaccurate sense. ${ }^{46}$ The same is true of the French term ordre public, which is just as vague as its English equivalent. ${ }^{47}$

According to Schwarzenberger, in the various jurisdictions' laws of obligations, or contracts, jus cogens means those rules that cannot be altered by the parties to the contract. E.g., labor laws protecting workers against instant dismissal are, mutatis mutandis, jus cogens rules. Even though an employment agreement expressly excludes the right, this regulation is void. This municipal version of $j u s$ cogens is absolute, prohibiting and ordering. It is contrasted with the notion of jus dispositivum, meaning rules, which the parties may alter. ${ }^{48}$ Municipal legal systems explain which rules are absolute, prohibiting and ordering, and therefore 'peremptory.' However, customary international law does not distinguish jus cogens from jus dispositivum. ${ }^{49}$ Also, according to Schwelb, only in municipal law, and not in international law, can courts decide a claim that a contract is void specifically for breaching a jus cogens norm. ${ }^{50}$

The conceptual move of jus cogens from municipal law into international law therefore suffers from a fallacy. Thus, as for the case of England, Attorney-General William Noy defined custom as a second law, which could be either general customs in use throughout the realm, called maxims, or particular customs used in some certain county, city, town or lordship. ${ }^{51}$ In this way, all customs were based on local

42 J. Bluntschli, Das moderne Volkerrecht der civilisirten Staten als Rechtsbuch dargestellt 234 (1st ed. 1868). See also A. Verdross, Jus Dispositivum and Jus Cogens in International Law, 60 Aм. J. InT'L L. 56-6 (1966).

43 French Civil Code (1803), art. 6. It provides that private agreements cannot derogate from laws, which affect ordre public and good morals.

44 G. Husserl, Public Policy and Ordre Public, 25 VA. L. Rev. 38 (1938).

45 Besant v. Wood, 12 Ch. D. 605, 620 (1879).

46 People v. Hawkins, 157 N. Y. 1, 12, 51 N. E. 257 (1898).

47 G. Cheshire, Private International Law 13 (1938). See also Husserl, supra note 44, at 40.

48 G. Schwarzenberger, International Law ANd Order (1971).

49 Schwelb, supra note 40.

50 Id.

51 W. Noy, The Grounds and Maxims and also an Analysis of the English Laws 39-41 (1808). 
issues. They could not be based on issues from abroad. Noy added that every maxim had a necessary and sufficient authority to itself, and only the municipal courts could finally determine what operated as a maxim. ${ }^{52}$ This was because only those learned in local affairs knew about the validity of maxims. He suggested that, if a maxim is construed strictly or absolutely, it should be jus cogens.

These rules specifically described local law. Oscar Schachter et al. observed that the international legal system could not develop in the same historical pattern as in national legal systems. National models centralized both norm setting and their policing as described above by Noy, whereas international systems did not. ${ }^{53}$ The cultural bases of human societies differed profoundly from one region of the world to another. ${ }^{54}$ Thus, international customary law traditionally had been considered as arising through the merely tacit agreement of states..$^{55}$ From the ancient Roman law, this view required that a general international practice be followed, ex opinione juris, ${ }^{56}$ in order to be a binding customary rule. ${ }^{57}$ The full phrase opinio juris sive necessitatis is Latin for "opinion about whether law or necessity." The court decides whether the state practice was legally required, or whether a state merely acted out of necessity or convenience. In Norwegian Fisheries, ${ }^{58}$ however, the ICJ held that a new rule of customary law could not be used against another state, which refused to be bound by it. ${ }^{59}$ Schachter et al. reasoned that this negative corollary of the doctrine of tacit consent would apply even in the less rigorous cases of international consensus. ${ }^{60}$

\section{B. The Origins of the Jus Cogens Concept in International Law}

Codifying an international form of jus cogens into the law of treaties comes from H. Lauterpacht's 1953 First Report on the Law of Treaties. ${ }^{61}$ In Article 15 of the draft, he proposed that: "A treaty, or any of its provisions, is void if its performance involves an act which is illegal under international law and if it is declared so to

52 Id.

53 Schachter, Sørensen \& Steiner, supra note 53, at 147 (1981). See generally A. Bozeman, The Future of LaW IN A Multi-Cultural World (1971).

54 Id.

55 Id.

56 J. Bederman, International Law Frameworks 15-6 (2001).

57 I.C.J. Statute art. 38(1). It reflects the same view in the phrase "a general practice accepted as law."

58 Norwegian Fisheries Case (U.K. v. Nor.), Judgment, 1951 I.C.J. Rep. 131 (Dec. 18).

59 Id.

60 Schachter, Sørensen \& Steiner, supra note 53, at 147.

61 First Report on the Law of Treaties, [1953] II Y.B. Int'l L. Comm'n 154, U.N. Doc. A/CN.4/SER.A/1977. U.N. Doc. A/CN.4/63. 
be by the International Court of Justice." inconsistency with customary international law pure and simple, but inconsistency with such overriding principles of international law which may be regarded as constituting principles of international public policy," or international ordre public. ${ }^{63}$ G. Fitzmaurice - Lauterpacht's successor Special Rapporteur on the International Law Commission - introduced an affirmative notion of 'consistency' with a general rule or principle of international law in the nature of jus cogens. ${ }^{64}$ However, $\mathrm{H}$. Waldock added:

The formulation of the rule, however, is not free from difficulty, since there is not as yet any generally accepted criterion by which to identify a general rule of international law as having the character of jus cogens. ${ }^{65}$

By contrast, in international law, the ordre public has been advocated at least since 1868 , as constituting theoretical statements. ${ }^{66}$ There appears to have been no reference to rulings of international courts, to state practice, or to any diplomatic procedures in correspondence, to explain the international ordre public. ${ }^{67}$

\section{Jurisprudence on International Jus Cogens}

Applying the 'learned scholars' formulation of ordre public, in S. S. Wimbledon, ${ }^{68}$ the Permanent Court of International Justice ("PCIJ") should decide whether Germany, while in 1921 a neutral during the Polish-Russian war, was obliged to allow contraband to travel the Kiel Canal on its way to Poland. The Court held that the Treaty of Versailles ${ }^{69}$ provided that the canal was to be open for use by all vessels registered in nations in a state of peace with Germany. ${ }^{70}$ The German national judge, Schücking dissented, however. He argued that, by allowing passage of the ship,

62 Id. at 154-6 (art. 15).

63 Id.

64 See Sir Humphrey Waldock, Special Rapporteur, Second Report on the Law of Treaties, [1977] II Y.B. Int'1 L. Comm'n 40, U.N. Doc. A/CN.4/156 and Add.1-3/1977.

65 Id. at 52.

66 J. Bluntschli, Das moderne Volkerrecht der civilisirten Staten als Rechtsbuch dargestellt 234 (1st ed. 1868). See Verdross, supra note 42, at 55-6.

67 Schwelb, supra note 40, at 949.

68 Case of the S.S. "Wimbledon" (U.K. et al. v. Germany), Judgment, 1923 P.C.I.J. (ser. A), No. 1 (Aug. 17).

69 Treaty of Peace between the Allied and Associated Powers and Germany, 28 June 1919, [1919] U.K.T.S. 4 (Cmd. 153).

70 Id. art. 380. 
Germany would violate a neutral's duty. Judge Schücking opined it could not have been the victorious states' intention to cause Germany to commit crimes against other states. Such an intention would be of no effect, because it was impossible to undertake by treaty any obligation to act, while violating third parties' rights. ${ }^{71}$ Judge Schücking again dissented in Oscar Chinn of $1934 .^{72}$ In this case, he held it possible to create a jus cogens rule, so that any act adopted in contravention of this kind of rule would be void. He reasoned, apparently applying a doctrine of ordre public, the PCIJ would not apply a convention that was contrary to learned scholars' formulations of public morality, ${ }^{73}$ as a consideration of international public policy. ${ }^{74}$

In the 1947/1948 case of United States against Alfried Krupp and others, ${ }^{75}$ the US Military Tribunal in Nuremberg charged the defendants with "employment of prisoners of war in ... work having a direct relation to war operations, including the manufacture and transport of armament and munitions," ${ }^{, 76}$ which was prohibited by the Geneva Prisoners of War Convention of 1929. ${ }^{77}$ In the 1949 Geneva Convention relative to the Treatment of Prisoners of War, ${ }^{78}$ which replaced the Convention of $1929{ }^{79}$ prisoners of war should not be compelled to do work in the metallurgical, machinery and chemical industries. ${ }^{80}$ The employment of prisoners of war in work, that had a connection with the operations of the war, was also prohibited by the Hague Conventions Respecting the Laws and Customs of War on Land of 1899 and $1907 .^{81}$ This was also a long-standing rule of customary international law. ${ }^{82}$

The defense counsel argued that the work arrangements had been authorized by an agreement between Germany and the Vichy Government, brokered by the French Ambassador in Berlin. The Tribunal held that while there was no credible evidence of this agreement, such an agreement would have been void under the law

71 Supra note 68. See also VCLT arts. 34-35.

72 The Oscar Chinn Case (U.K. v. Belg.), Judgment, 1934 P.C.I.J. (ser. A/B) No. 63 at 149-150 (Dec. 12).

73 A. von Verdross, Forbidden Treaties in International Law, 31 Am. J. INT’L L. 574 (1937).

74 Supra note 72.

75 See Trials of War Criminals before the Nürnberg Military Tribunals under Control Council Law, vol. IX, no. 10 (hereinafter Trials of the Nürnberg Military Tribunals) (US Gov’t. Printing Office, 1950). See also A. Verdross, Universelles Völkerrecht: Theorie und Praxis 172 (Duncker \& Humblot GmbH, 2010).

76 The Nürnberg Military Tribunals 29 (1950).

77 International Convention Relative to the Treatment of Prisoners of War, 27 July 1929, 118 L.N.T.S. 343, art. 31(1).

78 Geneva Convention Relative to the Treatment of Prisoners of War, 12 August 1949, 75 U.N.T.S. 135.

79 International Convention Relative to the Treatment of Prisoners of War, 27 July 1929, 118 L.N.T.S. 343.

80 Supra note 78.

81 Hague Conventions with respect to the Laws and Customs of War on Land of 1899 and 1907, art. 6, 29 July 1899.

82 W. Hall, International Law 132 (1st ed. 1870). 
of nations. ${ }^{83}$

The 1952 Federal Republic of Germany Equalization of Burdens Law ${ }^{84}$ purported to raise revenue for paying compensation to expellees and other war victims. The 1952 International Convention Relating to the Arrest of Sea-Going Ships, applying to the Federal Republic of Germany and Switzerland ${ }^{85}$ allowed application of the statute to Swiss nationals. A Swiss company petitioned the German Federal Constitutional Court, ${ }^{86}$ claiming that the German-Swiss Convention violated some general rule of international law - the state could not compel foreigners to pay taxes to be used in paying for war expenditures. ${ }^{87}$ Although the appellant did not characterize this rule of customary international law as jus cogens, the Court did interpret the pleading that way. It reasoned that most rules of customary international law were jus dispositivum and therefore replaceable by a treaty. The Court further stated that a few elementary legal commands should be rules of customary international law, where no derogation by treaty could be allowed. Such norms of jus cogens could only be those firmly grounded in the legal conviction of states, as 'indispensable' for an international legal order, meaning 'absolutely' necessary. According to the Court, the general rule that aliens could not be required to cover war costs would not be indispensable for an international legal order, and thus not a jus cogens. ${ }^{88}$

\section{International Crimes}

Some view the foundations of the concept of jus cogens, and customary international law, as being the same, ${ }^{89}$ while others differentiate them. ${ }^{90}$ The question remains open as to whether jus cogens is just another way of describing a specific range of general principles. ${ }^{91}$ This makes even more uncertain the status of jus cogens in international criminal law. A broad collation of judicial decisions, draft international codes and statutes, and other executive actions suggests a sufficient legal basis

83 Trials of the Nürnberg Military Tribunals 1395 (1950).

84 Equalisation of Burdens Law (1952) (F.R.G.), $\$ \S 91$ et seq.

85 International Convention Relating to the Arrest of Sea-Going Ships, (Brussels, May 10, 1952), accession by Switzerland 28/05/1954, with date of effect 24/02/1956.

86 Entscheidungen des Bundesverfassungsgerichts 441 (1965), reprinted in 13 Archiv des Völkerrecht (May 1966).

87 BVerfGE 18, 4412 BvR 227/64 Assessment of aliens for war taxation, April 7, 1965.

88 Schwelb, supra note 40, at 951.

89 A. D’Amato, The Concept of Custom in International Law 132 (1971).

90 G. Christenson, Jus Cogens: Guarding Interests Fundamental to International Society, 28 VA. J. INT'L L. 585 (1988). See also M. Janis, Jus Cogens: An Artful Not a Scientific Reality, 3 ConN. J. InT'L L. 370 (1988).

91 C. Bassiouni, Crimes Against Humanity in International Criminal Law 87 (1992). 
for the following international crimes as being classified as jus cogens violation: genocide, aggression, crimes against humanity, piracy, war crimes, slavery and slave-related practices, and torture. ${ }^{92}$ This legal basis comprises the following: (1) international declarations, or opinio juris; ${ }^{93}$ (2) declarations in preambles or other treaty provisions, indicating a higher status for these crimes in international law; ${ }^{94}$ (3) the sizeable number of states ratifying treaties concerning these crimes; ${ }^{95}$ and (4) international investigations and prosecutions of those committing these crimes. ${ }^{96}$

In Genocide, ${ }^{97}$ the ICJ held that the genocide prohibition was a jus cogens norm, not susceptible to reservation or derogation. ${ }^{98}$ In fact, the Court stated as follows:

It has nevertheless been argued that any State entitled to become a party to the Genocide Convention may do so while making any reservation it chooses by virtue of its sovereignty. The Court cannot share this view. It is obvious that so extreme an application of the idea of State sovereignty could lead to a complete disregard of the object and purpose of the Convention. ${ }^{99}$

In Military and Paramilitary Activities in and Against Nicaragua, ${ }^{100}$ the ICJ relied for its decision on a jus cogens norm, as a fundamental principle of international law. However, that case also shows the fragile basis of deploying legal principles to resolve contentious ideological or political matters, or the assessment of value judgments. ${ }^{101}$ The Court stated:

The United States, in its Counter-Memorial on the questions of jurisdiction and admissibility, found it material to quote the views of scholars that this principle is a "universal norm," a "universal international law", a "universally recognized principle

92 Bassiouni, supra note 18, at 68.

93 M. Akehurst, Custom as a Source of International Law, 47 BRIT. Y.B. InT'L L. 1 (1976).

94 Bassiouni, supra note 92.

95 Id.

96 M. Bassiouni, From Versailles to Rwanda in Seventy-Five Years: The Need to Establish a Permanent International Criminal Court, 10 Harv. Hum. RTs. J. 11 (1997). See also Bassiouni, supra note 18, at 68.

97 Reservations to the Convention on the Prevention and Punishment of the Crime of Genocide, Advisory Opinion, 1951 I.C.J. Rep. 15 (May 28).

98 Id. See also Convention on the Prevention and the Punishment of the Crime of Genocide of 1948, 78 U.N.T.S. 277; Bassiouni, supra note 18 , at 71 .

99 Supra note 97 , at 8.

100 Military and Paramilitary Activities in and Against Nicaragua (Nicar. v. U.S.), Judgment, 1986 I.C.J. Rep. 14 (June 27). See generally H. Maier, Appraisals of the ICJ's Decision: Nicaragua v. United States (Merits), 81 Am. J. INT'L L. 77 (1987).

101 See generally L. Damrosch \& D. Scheffer, Law and Force in the New International Order (1991). 
of international law", and a "principle of jus cogens". ${ }^{102}$

Since then, jus cogens has gained more the status of a text writers' communis opinio, meaning "common professional opinion," necessarily based in customary international law. As a principle within municipal law, scholarly text writers' communis opinio is said to be good authority in law. ${ }^{103}$ However, this leap of principle by analogy from municipal law to international law is far from fully cogent, as its premise is the hardly likely consensus of opinion of a group of learned scholars.

\section{E. Development of Jus Cogens}

Wright noted a problem of illegal treaties, based on judicial opinion in the 1916 judgment of Costa Rica v. Nicaragua, ${ }^{104}$ in the Central American Court of Justice. He denied the legal capacity of Nicaragua to execute the 1914 Bryan-Chamorro Treaty with the US. ${ }^{105}$ The Court decided that Article 2 of the Treaty, giving the US a 99year lease for a naval base in Nicaragua, in the Gulf of Fonseca, could not apply, as it derogated from El Salvador's and Honduras's customary international law rights to condominium in the Gulf of Fonseca. The Court upheld Costa Rica's contention that Article 1 of the Treaty conflicted with the Treaty of 1858 between Costa Rica and Nicaragua, protecting their boundary waters. ${ }^{106}$

This notion of jus cogens, as a restraint on derogation, had its early genesis as a constraint on cross-border freedom of contract. Verdross discussed it in detail, for the first time, in $1937 .{ }^{107}$ He wrote to respond to a report on the law of treaties, ${ }^{108}$ which omitted discussing the issue of a treaty whose terms conflicted with general international law. According to Verdross, the states' freedom to conclude treaties could be limited only when a treaty included the rules violating jus cogens. He found nothing in theory that would preclude this kind of rule. His conclusion was that a

102 Military and Paramilitary Activities in and Against Nicaragua (Nicar. v. U.S.), Judgment, 1986 I.C.J. Rep. 14, 9190 (June 27). See Documents of the twenty-second session, [1966] II Y.B. Int'1 L. Comm'n 247, U.N. Doc. A/CN.4/SER. A/1966. It reads: "The great majority of international lawyers today unhesitatingly hold that Article 2, paragraph 4, together with other provisions of the Charter, authoritatively declares the modern customary law regarding the threat or use of force."

103 E. Coke, The First Part of the Institutes of the Lawes of England. See also A Commentary upon Littleton (not the name of the author only, but of the law itself) $\S 180 \mathrm{a}(1684)$.

104 Costa Rica v. Nicaragua (Costa Rica v. Nica.), Judgment, 1916 Ctr. Am. Ct. of Justice (Sept. 30), translated and reprinted in 11 Am. J. INT'L L. 181 (1917).

105 Q. Wright, Conflicts between International Law and Treaties, 11 Am. J. INT'L L. 566 (1917).

106 Supra note 104.

107 Verdross, supra note 73, at 571; supra note 42, at 55.

108 See The Law of Treaties: Harvard Research in International Law, 29 Am. J. InT'L L. Supp. 655 (1935). 
compulsory norm of customary international law, such as the freedom of the high seas, would invalidate any agreement in which states sought to exclude other states from free use of the high seas. ${ }^{109}$

The law of treaties had long maintained that states could not, by the terms of a treaty, affect established rights of third states in the absence of their consent. ${ }^{110}$ This rule was codified in Articles 34 and 35 of the Vienna Convention on the Law of Treaties. ${ }^{111}$ Verdross's second category of jus cogens comprised general principles of public policy or morality "common to the juridical orders of all civilised states,"112 which he based on Article 38 of the PCIJ Statute. ${ }^{113}$ He found an 'unequivocal' principle, common to the decisions of national courts, regarding treaties as invalid when they "restrict the liberty of one contracting party in an excessive or unworthy manner or ... endanger its most important rights."114

As for which international treaties were immoral, Verdross suggested those which truncated any of the following: "(a) maintenance of law and order of the state; (b) defense against external attack; (c) care for the bodily and spiritual welfare of its citizens' homes; and, (d) protection of citizens abroad." ${ }^{\prime 115}$ He also described any treaty preventing a state from any one of these essentials as immoral. ${ }^{116}$

The scholarship contains long-posited objections to the source of international obligation lying in consent. A circular consensus is that this source must be based on an a priori, fundamental norm, imposing the duty to comply with freely accepted obligations. ${ }^{117}$ Schachter reasoned a 'processive' description of the forming of an obligatory norm. ${ }^{118} \mathrm{He}$ argued that five processes together constituted the necessary and sufficient conditions to establish any a priori mandatory legal norm. ${ }^{119}$ Schachter's five processes were: (a) a behavioral requirement; (b) the people with recognized competence and authority made the decision to designate the new $a$ priori norm; (c) an indication of state capacity and willingness to make the norm

\footnotetext{
109 Id. See also Verdross, supra note 73, at 571; supra note 42, at 55.

110 Verdross, supra note 73 , at 572

111 VCLT arts. 34-35.

112 Verdross, supra note 73, at 572.

113 P.C.I.J. Statute, L.N.T.S. 379, 390; 17 AM. J. InT’L L. Supp. 115 (1923).

114 Verdross, supra note 73.

115 Id. at 574.

116 D. Shelton, Normative Hierarchy in International Law, 100 Am. J. InT'L L. 299 (2006).

117 H. Kelsen, Pure Theory of Law 214-7 (1967). See also O. Schachter, Towards a Theory of International Obligation, 8 VA. J. INT'L L. 300 et seq. (1968). It identifies thirteen theories about the origin of obligation in international law.

118 Schachter, $i d$. at 319 .

119 Id. at 307.
} 
effective; (d) dissemination of the requirement to a specific audience; and, (e) the target audience had psychological and functioning responses suggesting that the designated requirement was sufficiently authoritative for on-going compliance. ${ }^{120}$ However, Schachter's essay concluded: "The whole process is purposive, directed to the satisfaction of interests and demands, hence pervasively value-oriented." ${ }^{\text {"121 }}$ Thus, when authorization for this a priori norm lay outside of such cumulative consent, there would arise a circularity of reasoning. ${ }^{122}$

\section{The Case Law}

\section{A. Torture and Cruel Treatment}

The European Court of Human Rights ("ECtHR") has maintained that an applicant must satisfy a specific standard to establish a claim under Article 3 of the European Convention of Human Rights ("ECHR"). ${ }^{123}$ In Ireland $v$. The United Kingdom, ${ }^{124}$ the ECtHR listed the sex, age, and victim's state of health, as factors to take into account for deciding the severity of treatment. ${ }^{125}$ The Court also held that forcing detainees into stress positions for long periods, exposing them to noise, starving them, and depriving them of sleep and drink, constituted ill-treatment, but not torture. ${ }^{126}$ Subsequent case law lowers the threshold for a finding of torture under the ECHR. ${ }^{127}$ Inflicting unnecessary physical force has been held to weaken human dignity and violate the European Convention. ${ }^{128}$

120 Id. at 308 .

121 Id. at 319.

122 Shelton, supra note 116 , at 302.

123 Wainwright v. The United Kingdom, 2006-X Eur. Ct. H.R. 807, ๆ 40.

124 Ireland v. United Kingdom, 23 Eur. Ct. H.R. (ser. B) (1976).

$125 \mathrm{Id}$. 99. For further case law applying the prohibition against torture and inhuman treatment to interrogation and detention of terrorists and organised crime, see Labita v. Italy [GC], 2000-IV Eur. Ct. H.R. 160; Selmouni v. France [GC], 1999-V Eur. Ct. H.R. 66; Chahal v. United Kingdom 23 Eur. H.R. Rep. 413 (1996).

126 Ireland v. United Kingdom, 23 Eur. Ct. H.R. (ser. B) ๆ 99 (1976).

127 Askoy v. Turkey, 1996-VI Eur. H.R. Rep. 2260 (1996); Selmouni v. France [GC], 1999-V Eur. Ct. H.R. 66; Chahal v. United Kingdom 23 Eur. H.R. Rep. 413 (1996).

128 Selmouni v. France [GC], 1999-V Eur. Ct. H.R. 66; Chahal v. United Kingdom 23 Eur. H.R. Rep. 413 (1996), [99]. 


\section{B. Psychological Anguish}

In Soering $v$. The United Kingdom, ${ }^{129}$ the ECtHr held that a person could not be extradited to the US, because he would suffer psychological harm if he were held there on death row. ${ }^{130}$ In Malawi African Association and Others v. Mauritania, referring to the African Charter on Human and Peoples' Rights, the Commission of Human and People's Rights held that any action with the objective of humiliation or causing psychological anguish may be torture or inhuman treatment, or violate the right to human dignity. ${ }^{131}$

In the 2001 case of Cantoral-Benavides v. Peru, ${ }^{132}$ the Inter-American Commission found that, according to prevailing international standards, torture might be inflicted by physical violence, and also by acts that generate severe physical, psychological or moral suffering. ${ }^{133}$ Holding similarly, in Maritza Urrutia, ${ }^{134}$ the Inter-American Court of Human Rights grounded its decision in the assumption that the prohibition of torture was a jus cogens. ${ }^{135}$ The Court found that the aggressive acts towards the victim might be categorized as physical and psychological torture, as they were specifically for wearing down the victim, to obtain from him self-incriminating evidence. ${ }^{136}$ Some cases have also discovered violations where relatives of victims of disappearance suffered anguish and the state failed to investigate properly and punish the wrongdoers. ${ }^{137}$ The 'Street Children' (Villagran-Morales et al) v. Guatemala case was the only case to have grounded its decision in an assumption that the prohibition of torture was a jus cogens. ${ }^{138}$

129 Soering v. The United Kingdom, 161 Eur. Ct. H.R. (ser. A) (1989).

130 For other cases involving the inflicting of mental, but not physical violence, see V. v. The United Kingdom, 1999 Eur. Ct. H.R. 171.

131 Malawi African Association and Others v. Mauritania, 149 African Comm'n H.P.R, Rep. No. 5/14, Communications 54/91, 61/91, 98/93, 164-196/97 and 210/9 (2000).

132 Cantoral Benavides v. Peru, Judgment, 2000 Inter-Am. Ct. H.R. (ser. C) No. 69, ๆ 43(b) (Aug. 18).

133 Id. at page 10.

134 Maritza Urrutia Case, Judgment, 2003 Inter-Am. Ct. H.R. (ser. C) No. 103 (Nov. 27).

135 Id. $\uparrow 92$ (holding jus cogens) \& 91, 93-94 (finding that the victim suffered physical violence amounting to torture, and mental violence constituting cruel and inhuman treatment).

136 Cantoral Benavides v. Peru, Judgment, 2000 Inter-Am. Ct. H.R. (ser. C) No. 69, ๆ 43(b) (Aug. 18). See supra note 134, at ๆๆ 91, 93-94.

137 See, e.g., María del Carmen Almeida de Quinteros et al. v. Uruguay, Communication No. 107/1981, U.N. Doc. CCPR/ C/OP/2, at 138, 14 (1990); Basilio Laureano Atachahua v. Peru, Communication No. 540/1993, U.N. Doc. CCPR/ C/56/D/540/1993, 8.7 (1996); Kurt v. Turkey, 1998 Eur. Ct. H.R 44, ๆๆ 58, 69 \& 125; Çakici v. Turkey, [1999] Eur. Ct. H.R 43, $\uparrow \uparrow ~ 85,98-99$.

138 Villagrán Morales et al. v. Guatemala, Judgment, 1999 Inter-Am. Ct. H.R. (ser. C) No. 63, ๆ 78 (Nov. 19). (referring to jus cogens at $9 \uparrow 2 \& 39)$. 


\section{Bodily Punishment}

The UN Human Rights Committee has held that corporal punishment is prohibited under Article 7 of the International Covenant on Civil and Political Rights ("ICCPR"). ${ }^{139}$ The African Commission held that corporal punishment violated the right to human dignity. ${ }^{140}$

\section{Detainees and Prisoners}

In Antti Vuolanne v. Finland, the Human Rights Committee determined that for punishment to be classed as degrading, the humiliation or debasement should exceed a certain level. ${ }^{141}$ It must have other elements beyond a deprivation of liberty. A court should consider all the circumstances, including the treatment's manner and duration, the mental and physical consequences, the victim's sex, state of health and age. $^{142}$

The Human Rights Committee held, in Polay Campos v. Peru, ${ }_{1}^{143}$ that publicly displaying the victim in a container and separating him in a small cell for 23 hours per day, with ten minutes of sunlight per day, violated both Articles 7 and 10 of the ICCPR ${ }^{144}$ on inhuman treatment and treatment of persons deprived of liberty, respectively. ${ }^{145}$

In International Pen and Others v. Nigeria, ${ }^{146}$ the African Commission on Human and Peoples' Rights held that where the state detained people in leg irons and hand cuffs, while they were sentenced to death, and denied them access to lawyers and required medications, it violated Article 5 of the African Charter on Human and Peoples' Rights, as to human dignity. ${ }^{147}$

In Ribitsch v. Austria, ${ }^{148}$ the ECHR also expounded reverse onus presumptions on

139 George Osbourne v. Jamaica, Communication No. 759/1997, U.N. Doc. CCPR/C/68/D/759/1997 (2000), at 9 9.1; ICCPR art. 7.

140 Curtis Francis Doebbler v. Sudan, Communication No. 236/2000, Afr. Comm'n H.P.R. ๆ 38. (May 29, 2003).

141 Antti Vuolanne v. Finland, Communication No. 265/1987, U.N. Doc. Supp. No. 40 (A/44/40) at 311 (1989).

142 Id. at 9.2 .

143 Polay Campos v. Peru, Human Rights Committee, Communication No 577/1994*, U.N. Doc. CCPR/C/61/D/577/1994 (1997).

144 ICCPR art. 7.

145 Id. See also Loayza Tamayo v. Peru, Judgment, 1997 Inter-Am. Ct. H.R. (ser. C) No. 33, ๆ 46(a) (Sept. 17). (It finds that similar treatment violated the applicants' rights under the American Convention).

146 International Pen and Others on behalf of Saro Wiwa v. Nigeria, Communications 137/94, 139/94, 154/96 and 161/97, AHRLR 212 (ACHPR 1998).

147 Id. at 9 ब 280.

148 Ribitsch v. Austria 336 Eur. Ct. H.R. (Ser. A) 26 (1995). 
ill treatment by states. The Court stated:

The Commission expressed the view that a State was morally responsible for any person in detention, since he was entirely in the hands of the police. In the event of injuries being sustained during police custody, it was for the government to produce evidence establishing facts which cast doubt on the account of events given by the victim, particularly if this account was supported by medical certificates. ${ }^{149}$

\section{E. Death Penalty}

The Human Rights Committee has held that the means of imposing the death penalty could violate the right to freedom from torture, cruel, inhuman or degrading punishment. ${ }^{150}$ The Committee found that death by lethal injection was not cruel and inhuman, despite evidence that these injections could entail extreme suffering. ${ }^{151}$

In Al-Saadoon and Mufdhi v. The United Kingdom, ${ }^{152}$ the ECHR determined hanging to be an "ineffectual and extremely painful method of killing, such as to amount to inhuman and degrading treatment." "153 The Court stated that: "Whatever the method of execution, the extinction of life involves some physical pain, as well as intense psychological suffering deriving from the foreknowledge of death."154 The InterAmerican Commission on Human Rights has held that a lethal injection causes an unacceptable risk of agonizing pain and suffering to the subject. ${ }^{155}$

The mental anguish cases also include the so-called "death row phenomenon," referring to detainees suffering inhuman and degrading while on death row, as independent of detainees' right to life. ${ }^{156}$ The Human Rights Committee has not found detention on death row to violate the right to be free from torture and ill-treatment. The Committee will only find violations when there are additional and compelling circumstances. Examples would include either documented deterioration of the

149 Id. at 931.

150 Human Rights Commission Res. 2003/67, ๆ 4(i); Res. 2004/67, ๆ 4(i); and Res. 2005/59 ๆ 7(i) (stating that stoning is cruel and inhuman); Chitat Ng v. Canada, Communication No. 469/1991, U.N. Doc. CCPR/C/49/D/469/1991 (1994). Mr. Bertil Wennergren's individual opinion notes that use of a gas chamber to execute criminals is cruel and inhuman.

151 Cox v. Canada, Communication No. 539/1993, U.N. Doc. CCPR/C/52/D/539/19930. (1994), [17.3].

152 Al-Saadoon and Mufdhi v. the United Kingdom, 2010-II, Eur. Ct. H.R. 282, 1114 (2010). It states: "The Convention was a multilateral treaty containing erga omnes partes human rights obligations."

153 Id. 182.

154 Id. 1115.

155 Inter-Am. Ct. H.R., Rep. No. 63/12, Petition 1762-11, Virgilio Maldonando Rodriguez (US) (Mar. 29, 2012), available at http://www.oas.org/en/iachr/decisions/admissibilities.asp (last visited on Oct. 17, 2017).

156 Soering v. The United Kingdom, 161 Eur. Ct. H.R. (ser. A) (1989); Ilaşcu and Others v. Moldova and Russia, 2004-VII Eur. Ct. H.R. 1030, ๆศ 235, 241, 417, 429, 430 \& 440 (2004). 
subject's mental health, or the victim's vulnerability by virtue of age or status. ${ }^{157}$ Similarly, in the Inter-American system, both Hilaire, Constantine and Benjamin et al v. Trinidad and Tobago, ${ }^{158}$ and the 2005 Case of Raxcacó-Reyes v. Guatemala ${ }^{159}$ have grounded their decisions in a prohibition of torture being a jus cogens.

\section{Conclusion}

A broad collation of judicial decisions, draft international codes and statutes, and other executive actions suggests a sufficient legal basis for the crime of torture to be classified as the violation of jus cogens. It appears jus cogens is discovered by scholar's views of executive actions.

In the Genocide Case, ${ }^{160}$ the ICJ stated that it could not share the view that any State entitled to become a party to the Genocide Convention might become a party while making any reservation it chose by virtue of its sovereignty. ${ }^{161}$ It held this would be so extreme an idea of state sovereignty as to destroy the Convention's object and purpose. Otherwise this suggested that states could claim sovereign immunity from a jus cogens rule, thereby destroying the Convention that had set up the rule.

In Military and Paramilitary Activities in and Against Nicaragua, Nicaragua stated in the ICJ that the principle prohibiting the use of force embodied in Article 2, paragraph 4 of the UN Charter had come to be recognized as jus cogens. ${ }^{162}$ The US quoted the views of uncited scholars that this was a universally recognized principle of international law, i.e., jus cogens. ${ }^{163}$ Both arguments suggested that discovery of a jus cogens norm was an administrative act.

157 Errol Johnson v. Jamaica, Communication No. 588/1994, U.N. Doc. CCPR/C/56/D/588/1994 (1996), [8.1], [8.5], [8.6]; Clive Johnson v. Jamaica, Communication No. 592/1994: Jamaica. 25/11/98, U.N. Doc. CCPR/C/64/D/592/1994 (Nov. 25, 1998), ๆๆ 6.5, $9.3 \& 10.3$.

158 Hilaire v. Trinidad and Tobago, Preliminary Objections, 2001 Judgment, Inter-Am. Ct. H.R. (ser. C) No. 80, ๆ 2(b) (Sept. 1), referring to jus cogens at 16.

159 Raxcacoó-Reyes v. Guatemala, Merits, Reparations and Costs, Judgment, Inter-Am. Ct. H.R. (ser. C) No. 133, ๆ 3 (Sept. 15, 2005), referring to jus cogens at $₫ 22$.

160 Supra note 97.

161 Id. at 173.

162 Military and Paramilitary Activities in and Against Nicaragua (Nicar. v. U.S.), Judgment, 1986 I.C.J. 14, 190 (June 27).

163 Id. $\uparrow$ 101. It refers to Documents of the Twenty-Second Session, [1966] II Y.B. Int'l L. Comm'n 247, U.N. Doc. A/ CN.4/SER.A/1966. 
Now, it appears that jus cogens has more the status of a text writers' communis opinio, necessarily based in customary international law, and informing administration acts of recognition. The text writers' communis opinio is said to be good authority in municipal law. However, this leap of principle by analogy from municipal law to international law is far from fully cogent, as it suggests either an unlikely or ephemeral consensus of opinion of a group of learned scholars with overriding group influence.

Although there is no positive evidence of jus cogens in any of the Roman law, the Roman sources do demand a general international practice should be followed, ex opinione juris, to bind other states as a customary rule. This requires an opinion about whether the state of affairs is law or necessity. In making this decision, the discovery of a new rule of customary law could not be used in any argument against a state party. This limits the ability of one state to declare an enemy of all mankind and bind all other states. To discover a breach of a jus cogens norm, courts seek inconsistency with overriding principles of international law, which could be construed as principles of international ordre public. Judge Schücking reasoned a court would not apply a convention that was contrary to scholastic formulations of public morality, as a consideration of international public policy. From collations of the texts, it appears jus cogens is discovered primarily by scholar's views of executive actions; it implies that state executives could also claim a reasoned sovereign immunity from a jus cogens, thereby destroying the purpose of a universal convention. Thus, discovery of a jus cogens norm is a purely administrative act. Jus cogens arguably has more the status of a text writers' municipal communis opinio, but newly held to be based in customary international law. However, this leap from municipal law to international law is far from fully cogent. From the case law, any prohibition against torture appeared to be municipal customary law, breaches of which therefore were proved as arguments based on fact. In the cases where courts based their anti-torture decision on jus cogens norms, the localized nature of the forums inferred an absence of erga omnes obligations. In the Human Rights Committee cases, the non-judicial nature of the forum for these decisions similarly inferred an absence of erga omnes obligations. 
